conference to be held between March and May. The conference is expected to attract 300 attendees.

Coalition for Networked Information. The Board heard a report from Thomas Kirk and Noreen Alldredge, representatives to the Task Force of the Coalition for Networked Information. Kirk and Alldredge see their role as that of bringing as much information as possible to the ACRL membership as well as helping the Coalition meet its objectives.

Joint Committee on the Definition of Membership Services. The Board approved the report from the Subcommittee, made up of both members of the Membership Committee and the Budget and Finance Committee. The report presented proposals which identified three categories for ACRL services and programs: a) basic membership services fully covered by membership dues, b) services and programs on a cost-recovery basis, and c) programs designed to produce net revenue.

ACRL Board Retreat. The Board agreed that the ACRL Strategic Plan, which was developed in 1986, should be reviewed. The Board will meet in Salt Lake City, April 11, in a planning retreat to review and develop strategies for a 1993-1995 strategic plan.

Constitution and Bylaws. The Board voted to change the makeup of the ACRL Board of Directors to include the Chair of the Planning Committee as an ex-officio member of the Board. The member- ship will vote on this constitutional change to the bylaws in the spring election.

WHCLIS. The Board endorsed the resolution put forth by the ACRL White House Conference Task Force and the Governmental Relations Committee that ACRL adopt the three top priority action issues of the conference as priority action areas for ALA. The three priority issues are: Omnibus Children and Youth Literacy; NREN available in all libraries and other information repositories at all levels; a national, regional, state, and local commitment of financial resources for library services.

Planning Committee. The Board accepted reviews of four committees: Audiovisual, Constitution and Bylaws, Budget and Finance, and Academic Status, and approved the continuance of the work of these committees.

Taxation on Periodical Subscriptions. The Board endorsed the resolution from ALCTS against taxation of periodicals subscriptions.

Improvement of Information Act. The Board endorsed the resolution from GODORT.

Sixth National Conference-Salt I ake City. Executive Committee Chair Joseph Boissé reported that things are going well. Exhibitors are past $100 \%$ of the projected numbers and budget. An outstanding program has been arranged and we are now looking forward to a very large conference registration.

\title{
A career in BI: Dead end or stepping stone?
}

Choosing a career in bibliographic instruction (BI) was the topic for discussion at the January 26 , Midwinter discussion forum sponsored by the Bibliographic Instruction Section's Continuing Education Committee. Discussion starter Evan Farber, Earlham College, remarked that many of the qualities that make a good BI librarian are also qualities that make a successful library administrator. BI librarians must be in touch with issues in higher education and all aspects of the library and have political skills. He recounted the number of recent ACRL presidents that have come from the ranks of bibliographic instruction.

Karen Williams, University of Arizona, Pointed out that a successful career does not necessarily mean moving up the career ladder, and viewed BI as a useful stepping stone to a number of different career paths. Williams said that BI librarianship could be a dead end unless it is combined with other duties, such as working at the reference desk, in order to remain in touch with issues and operations in other areas of the library.

Bill Miller, Florida Atlantic University, stated that there were fewer chances for supervisory experience working in the public services and this could be a hindrance to job advancement. $\mathrm{He}$ also remarked that bibliographic instruction librarians have the closest ties to faculty in their roles as teachers.

Members of the audience agreed and felt that their interactions and common interests with the faculty had enhanced their standing with the university community. Comments from the audience indicated that many enjoyed their work in $\mathrm{BI}$ and did not see it as hindrance or a dead-end job. The hour ended with a discussion about why BI is not part of the curriculum at many library schools, or is taught by practitioners instead of library school faculty.--Jill Newby, Engineering Librarian, Yale University 


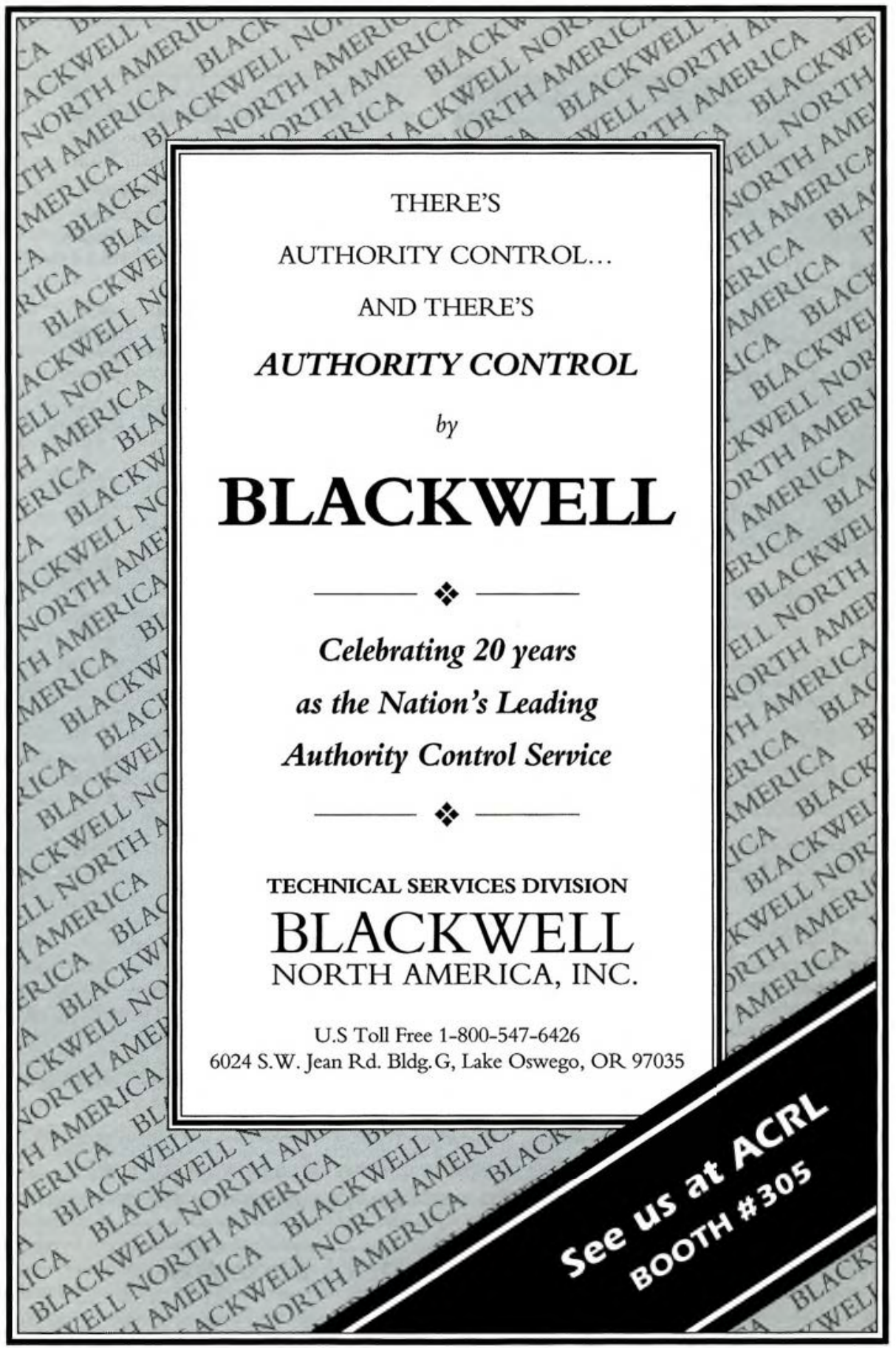




\section{When quality}

\section{and service count...}

\section{More libraries are}

\section{For database preparation and authority control:}

$\checkmark$ WLN MARC Record Service (MARS)

Complete database preparation including duplicate deletion, holdings merging, record upgrade, item record conversion and smart bar codes.

$\checkmark$ Authority control: LC NAF/SAF or WLN authority file matching and heading upgrade; manual review; output of USMARC authority records.

$\checkmark$ Retrospective conversion: Shelfilist conversion and non-MARC to MARC record conversions and upgrades.

$\checkmark$ Output products: Your upgraded bibliographic records and USMARC authority records on MARC tapes or CD-ROM catalogs.

\section{For online and CD-ROM databases:}

$\checkmark$ WLN Onlins System: Over 7 million bibliographic records under full authority control; powerfulsearching; sophisticated online cataloging; online LC NAF/SAF File; full-feature Interlibrary Loan and Acquisitions Systems; MARC record download or tape to local systems.

LaserCat8: A 3.6 million record database on CD-ROM; catalog card, label, bibliography printing: MARC record downloading to local systems; powerful searching; original cataloging; retrospective conversion.

$\checkmark$ LaserPaciu: This public access version of LaserCat provides your bibliographic records and holdings including individual call numbers and cross references. The ideal catalog both for individual libraries and consortia.

\section{For collection assessment} services:

WLN Conspectus Service: A nationally recognized method for assessing both Dewey and LC classified collections. WLN's Conspectus software lets you build your own assessment database and print your own reports.

$\checkmark$ WLN Collection Analysis Reports: Offers precision analysis of your collection by Conspectus subject categories, date ranges and a variety of other criteria. A powerful collection analysis tool for single institutions or groups.

$\checkmark$ WLN BCL3 Service: Compares your collection against the 3rd edition of Books for College Libraries accurately and efficiently. Miss, match and close match reports can be arranged by BCL3 number order or Conspectus subject categories.

Comprehensive. High quality. Flexible. Affordable. That's what librarians are saying about WLN. Isn't it time you put WLN products and services to work for you? WLN, 4224 6th Ave., Bldg. 3, Lacey, WA 98503 1-800-DIALWLN (206) 459-6518 FAX (206) 459-6341

\section{$\boldsymbol{U} / \mathbf{h}$... see us at ACRL, Booth 609}

